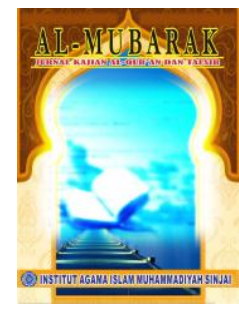

\title{
REVITALISASI IPTEK MODERN DALAM GAGASAN ILMUAN DAN PERSPEKTIF ISLAM
}

\author{
Umar', Siar Ni' mah $^{2}$ \\ ${ }^{1}$ Institut Agama Islam Muhammadiyah Sinjai \\ ${ }^{2}$ Institut Agama Islam Muhammadiyah Sinjai \\ E-mail: oemar.tech.iaim@gmail.com, Tlp:+6285255199273
}

\begin{abstract}
Abstrak
Globalisasi Abad 21 dan Revolusi Industri 4.0 menyebabkan terjadinya gelombang besar teknologi sebagai kemajuan ilmu pengetahuan dalam peradaban modern. Orientasi manusia makin takluk pada ilmu pengetahuan dan teknologi (Iptek) modern yang bebas nilai bahkan menjauh dari eksistensi Tuhan dan ajaran Islam padahal epistemologis Iptek bersumber dari ajaran Islam. Tulisan ini bertujuan menggarisbawahi kembali khazanah Iptek modern yang sejalan dengan nilai-nilai Islam agar manusia sebagai pengembang, teknolog, dan ilmuan tak terjebak makin dalam pada lorong gelap sains dan teknologi yang jauh dari cahaya Islam. Melalui metode kajian kualitatif pendekatan library research ditelaah sumber otentik dari buku-buku, jurnal, artikel online maupun fakta empiris kemudian disimpulkan. Khazanah Iptek modern kini inovatif manusia makin berkembang secara dinamis dan terdapat kecenderungan pada pengikisan hakikat kemanusiaan dan keislaman. Gagasan ilmuan Islam dalam beberapa dekade telah memprakarsai revitalisasi ini sehingga penting paradigma ajaran Islam senantiasa ditempatkan lebih strategis di atas promosi dan gagasan Iptek dalam berbagai konteks kehidupan modern baik tantangan dan perubahannya termasuk implikasinya dalam pendidikan Islam.
\end{abstract}

Kata Kunci: Iptek Modern, Revitalisasi, Ajaran Islam

\section{Pendahuluan}

Memperbincangkan Ilmu Pengetahuan dan Tekhnologi (Iptek) dalam pembahasan ini terdapat dua variabel pembahasan yang membutuhkan pencermatan yakni Iptek sebagai sarana media dan Islamisasi Iptek sebagai konsep yang telah dikembangkan sejak lama oleh ilmuan muslim diawal tahun 1980-an. Iptek sebagai bagian dari ilmu-ilmu sosial menurut (Marsuki, 1995) telah digagas dan dikembangkan ilmuan muslim seperti Islami Razi Al-Faruqi, Syed Muhammad Al-Naquib Al Attas, Ziauddin Sardar dll. Konsep ini dimaksudkan guna mengingatkan kembali segenap khalayak khususnya masyarakat Islam dalam memaknai pentingnya Iptek yang berbasis nilai-nilai 


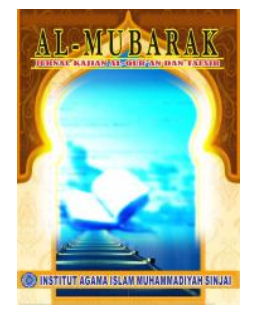

AI-MUBARAK

Jurnal Kajian Al-Quran \& Tafsir

Volume 5, No. 1, 2020

P-ISSN: 2548-7248

E-ISSN: 2715-5692

Homepage : http://journal.iaimsinjai.ac.id/indeks.php/al-mubarak

teologis Islam. Dalam konteks ini menurut (Dwijo, Al., 2016) pengembangan Iptek sangat dianjurkan dalam ajaran hukum Islam.

Iptek bukan lagi sesuatu yang asing ditelinga. Adanya kemajuan dan kemudahan yang terjadi atas kehidupan manusia merupakan peran dari Iptek yang telah dikembangkan manusia dari masa kemasa. Dengan demikian Iptek memudahkan urusan manusia dan memenuhi kebutuhannya atau mengantarkan kehidupan manusia menjadi lebih baik. Era globalisasi merupakan era yang tidak dapat lagi dihindari oleh manusia, penuh dengan polemik tantangan, kompetisi dan persaingan dalam berbagai bidang telah berlangsung demikian ketat. Dalam peradaban manusia dipersepsikan bahwa hanya dengan sumber dayalah atau memiliki ilmu pengetahuan akan mampu menguasai era tekhnologi dan kompetisi global tersebut.

Iptek sangat penting bagi umat manusia dan terlebih umat Islam khususnya. Dalam historis dan peradaban manusia, bersamaan muncul dengan ilmu pengetahuan yang digunakan untuk menciptakan teknologi. Sehingga tekhnologi merupakan produk ilmu pengetahuan melalui pengembangan dan menjadi parameter kemajuan peradaban manusia. Iptek berkembang demikian pesatnya melahirkan tantangan luar biasa bahkan membawa manusia jauh dari nilai spiritualisme agama, padahal pengembangan tekhnologi tidak boleh melepaskan diri dari nilai-nilai agama. Albert Einstein berujar "Agama tanpa ilmu akan pincang, sedangkan ilmu tanpa agama akan buta”, menyiratkan pentingnya posisi agama dalam pengembangan ilmu pengetahuan.

Dalam historisnya agama Islam telah mengambil peran dengan membawa kejayaan ilmu pengetahuan masa lalu, dan tetap mengawal perkembangan ilmu pengetahuan dan tekhnologi yang digagas oleh Barat selama satu abad terakhir. Peradaban barat modern dan postmodern sangat memperlihatkan kemajuan dan menjanjikan kebahagiaan hidup manusia. Iptek yang lahirkannya masa kini disisi lain membawa kecenderungan manusia pada pandangan dunia (iptek) yang positivistik-empirik, materialisme--sekuler, pragmatis, kehancuran (manusia dan lingkungan) sehingga mendapat dukungan bahwa ilmu yang objektif itu bebas nilai. Ancaman tersebut dapatlah bertentangan dengan nilai-nilai Islam. Maka 


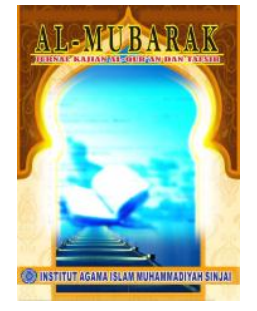

AI-MUBARAK

Jurnal Kajian Al-Quran \& Tafsir

Volume 5, No. 1, 2020

P-ISSN: 2548-7248

E-ISSN: 2715-5692

Homepage : http://journal.iaimsinjai.ac.id/indeks.php/al-mubarak

melalui potret đan krisis yang terjadi ini sehingga agama Islam memberikan perspektif dan para pemikir-pemikir intelektual Islam mengambil langkah dengan Islamisasi pengetahuan sebagai pemecahan masalah dan mengembalikan ruh ilmu pengetahuan sebagai rahmatan lilalamin. Sejalan yang dikemukakan (Alwi, M. 2017) dengan islamisasi ilmu pengetahuan diharapkan mengatasi krisis masyarakat modern melalui penguasaan ilmu-ilmu pengetahuan modern dan kembali warisan Islam melalui pengkajian.

Tulisan ini mengkaji tentang Ilmi Pengetahuan dan teknologi (Iptek), Iptek sebagai kebutuhan dan tantangan, Iptek modern dan ajaran Islam, Al-Qur'an sebagai sumber inspirasi ilmu pengetahuan, Urgensi gagasan ilmuan tentang islamisasi Iptek modern dan pentingnya meletakkan khazanah Iptek dan implikasinya dalam pendidikan Islam. Hal ini bertujuan memberikan informasi disela pesatnya perkembangan global dan teknologi modern masa kini yang selalu membutuhkan landasan epistemologis Islam dan mempromosikan kembali pentingnya Iptek dalam wacana nilai-nilai dan implikasi pendidikan Islam.

\section{Metode}

Jenis penelitian ini adalah kualitatif dengan pendekatan library research yakni penulis menelaah berbagai sumber-sumber referensi kepustakaan. Target dan sasaran penelitian ini adalah mengemukakan kembali pentingnya landasan epistemology Islam dalam pengembangan Iptek modern sebagaimana lebih awal dipromosikan para ilmuan Islam dan pentingnya khazanah Iptek dalam pendidikan Islam. Teknik pengumpulan data dilakukan melalui telaah buku-buku, jurnal, artikel online yang relevan dengan tema dan dianalisis berdasarkan pandangan-pandangan pakar yang ramu dengan kesimpulan-kesimpulan empiris kemudian terbangun argumen-argumen konstruktif sehingga menjadi uraian dan kesimpulan akhir dalam artikel ini.

\section{Pembahasan}

\subsection{Ilmu Pengetahuan dan Teknologi (Iptek)}

Iptek atau sebutan sains dan technology menurut (Tjaya, H. T, 2002:85) merupakan dua buah kata yang melambangkan kemajuan dan modernitas yang 


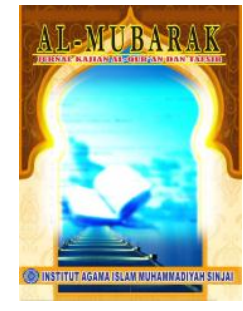

AI-MUBARAK

Jurnal Kajian Al-Quran \& Tafsir

Volume 5, No. 1, 2020

P-ISSN: 2548-7248

E-ISSN: 2715-5692

Homepage : http://journal.iaimsinjai.ac.id/indeks.php/al-mubarak

sering dirangkai begitu saja. Perangkaian ini memang tiđak keliru karena munculnya tekhnologi modern bukan merupakan akibat sekunder dari sains. Sebaliknya, sudah sejak awal mula, riset tekhnologi menuntun riset ilmiah (sains) lewat trial and error. Istilah ilmu pengetahuan diambil dari kata bahasa Inggris science, yang berasal dari bahasa Latin scientia dari bentuk kata kerja scire yang berarti mempelajari, mengetahui. Pertumbuhan selanjutnya pengertian ilmu mengalami perluasan arti sehingga menunjuk pada Islam, berikut terlebih dahulu didefinisikan antara ilmu dan pengetahuan.

a. Paradigma Ilmu Pengetahuan

Ilmu adalah pengetahuan yang dimiliki oleh manusia. Sedangkan pengetahuan adalah hasil dari aktivitas manusia tentang mengetahui segala sesuatu sehingga tidak diragukannya. Dalam Kamus Besar Bahasa Indonesia, pengetahuan adalah tentang suatu bidang yang disusun secara bersistem menurut metode-metode tertentu yang dapat digunakan untuk menerangkan gejala-gejala tertentu dibidang (pengetahuan) itu (Retnoningsih, A \& Suharso, 2011:178).

Gabungan "ilmu dan pengetahuan", para ahli mendefinisikan, seperti Gazalba dalam Siregar mengemukakan jika pengetahuan adalah apa yang diketahui atau hasil pekerjaan tahu. Pekerjaan tahu tersebut adalah hasil dari kenal, sadar, insaf, mengerti, dan pandai (Siregar, M, 2013:48). Ashly Mountagu dalam bukunya The Cultured Man menyebutkan bahwa "science is a systematized knowledge services from observation, study, and Experimentation carried on order to determaine the natureor principles of what being studied" (ilmu adalah pengetahuan yang disusun dalam satu system yang berasal dari pengalaman, studi dan pengalaman, studi dan pengalaman untuk menetukan hakikat dan prinsip tentang sesuatu yang sedang dipelajari ) (Siregar, M, 2013:51). Oleh karena itu ilmu pengetahuan adalah pengetahuan yang dimiliki oleh manusia yang didapatkan melalui proses dan studi berbeda baik melalui pengalaman, eksprimen, klasifikasi-reduksi dan observasi, dan lain-lain serta menggunakan strategi dan metode berpikir secara objektif untuk memberi nilai dan makna sehingga dapat dimanfaatkan dalam dimensi kehidupan manusia. 


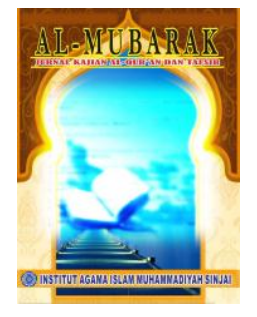

AI-MUBARAK

Jurnal Kajian Al-Quran \& Tafsir

Volume 5, No. 1, 2020

P-ISSN: 2548-7248

E-ISSN: 2715-5692

Homepage : http://journal.iaimsinjai.ac.id/indeks.php/al-mubarak

Menurut Quraish Shihab dalam (Nizar, S \& Ramayulis, 2009:75)

mengemukakan bahwa kata ilmu dalam berbagai bentuk terdapat 854 kali dalam al-Qur'an. Kata ini digunakan dalam proses pencapaian tujuan, ilmu dari segi bahasa berarti kejelasan jadi ilmu pengetahuan adalah pengetahuan yang jelas tentang sesuatu. Pengetahuan yang tidak jelas dari segi ontology, epistemology, maupun aksiologi di dalam Islam tidak dianggap sebagai ilmu walaupun orang menyebutnya ilmu juga. Persoalan hakikat ilmu pengetahuan atau apa sebenarnya ilmu pengetahuan (ontology). Telah menjadi perdebatan antara kaum materialis dan kaum idealis. Kaum materialis hanya mengenal pengetahuan yang bersifat empiris, dengan pengertian bahwa pengetahuan hanya diperoleh dengan menggunakan akal atau indera yang bersifat empiris dan terdapat di alam materi yang ada di dunia ini. Sedangkan kaum idealis, termasuk Islam, ilmu pengetahuan bukan hanya diperoleh dengan perantaraan akal dan indera yang bersifat empiris saja, tetapi juga ada pengetahuan yang bersifat inmateri, yaitu pengetahuan yang berasal dari Allah sebagai khalik (pencipta) pengetahuan tersebut.

Ilmu dikembangkan melalui aktivitas manusia dengan metode tertentu sehingga aktivitas metodis itu mendatangkan pengetahuan yang sistematis. Aktivitas ilmiah ini dapat berwujud penelaahan (study), penyelidikan (inquiry), usaha menemukan (attempt to find) atau pencarian (search). Oleh karena itu, pencarian biasanya dilakukan berulang kali, maka dalam dunia ilmu kini dipergunakan istilah yang paling berbobot guna menemukan pengetahuan baru. Metode ilmiah merupakan prosedur yang mencakup berbagai tindakan pikiran, pola kerja tata langkah, dan cara tekhnis untuk memperoleh pengetahuan baru atau memperkembangkan pengetahuan yang ada. Metode yang berkaitan dengan pola prosedural meliputi pengamatan, percobaan, pengukuran, survey, deduksi, induksi, analisis, dan lain-lain. Berkaitan dengan tata langkah meliputi penentuan masalah, perumusan hipotesis (bila perlu), pengumpulan data, penurunan kesimpulan, dan pengujian hasil, Ihsan F, A, H, 2011:109-110). Hasil pengujian tersebut yang telah tersusun dan sistematis seperti yang telah dikemukakan oleh ilmuan sebagai ilmu. 


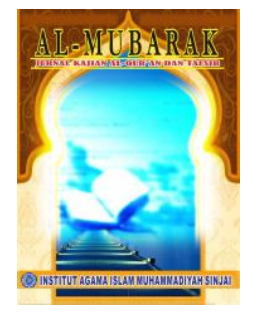

AI-MUBARAK

Jurnal Kajian Al-Quran \& Tafsir

Volume 5, No. 1, 2020

P-ISSN: 2548-7248

E-ISSN: 2715-5692

Homepage : http://journal.iaimsinjai.ac.id/indeks.php/al-mubarak

Persoalan dalam ilmu sebagai skema pengetahuan dipecahkan melalui riset

metodis untuk memperoleh jawaban, sehingga ilmu diperoleh melalui adanya persoalan yang berkembang. Dan masalah dalam ilmu harus terpecahkan secara seksama. Pemecahan masalah ini kemudian melahirkan kejelasan dan kebenaran walau pun kebenaran demikian tidak mutlak dan akan dipatahkan oleh kebenaran baru yang kemudian dapat dujicobakan oleh orang lain untuk memperoleh pembenaran dan atau penolakan/penyangkalan.

Menurut The Liang Gie ilmu pengetahuan atau pengetahuan ilmiah mempunyai ciri pokok yaitu; Pertama, Empiris, pengetahuan itu diperoleh berdasarkan pengamatan dan percobaan. Kedua, Sistematis, berbagai keterangan dan atau yang tersusun sebagai kumpulan pengetahuan itu mempunyai hubungan ketergantungan dan teratur. Ketiga, Objektif, ilmu berarti pengetahuan itu bebas dari prasangka perseorangan dan kesukaan pribadi. Keempat, Analitis, pengetahuan ilmiah berusaha membeda-bedakan pokok soalnya kedalam bagian yang terperinci untuk memahami berbagai sifat, hubungan, dan peranan dari bagian-bagian itu. Kelima, Verifikatif, dapat diperiksa kebenarannya, oleh siapa pun juga (Ihsan F, A, H, 2011:112-113).

b. Paradigma Tekhnologi

Ilmu adalah sumber teknologi yang mampu memberikan kemungkinan munculnya berbagai penemuan rekayasa dan ide-ide. Adapun teknologi adalah terapan atau aplikasi dari ilmu yang dapat ditunjukkan dalam hasil nyata yang lebih canggih dan dapat mendorong manusia untuk berkembang lebih maju lagi (Firmanto, T, 2013). Tekhnologi adalah kemampuan teknik yang berlandaskan pengetahuan ilmu eksakta yang berdasarkan proses teknis, ilmu teknik (Retnoningsih, A \& Suharso, 2011:542). Menurut Paul W. Devore tekhnologi adalah ilmu terapan yang dikembangkan lebih lanjut, dan meliputi perangkat keras dan perangkat lunak yang merupakan manifestasi atas kekuasaan alam, manusia dan kebudayaannya (Ihsan F, A, H, 2011:112-143). Tjahyadi, S. merangkum berbagai definisi atas, pertama teknologi adalah penerapan ilmu, kedua, teknologi adalah ilmu yang dirumuskan dalam kaitan dengan aspek eksternal, yaitu industri, dan aspek internal yang dikaitkan dengan objek material 


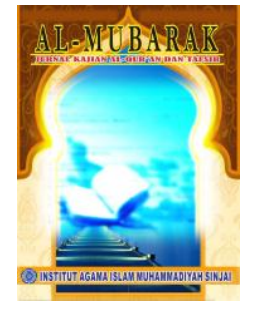

\section{Al-MUBARAK}

Jurnal Kajian Al-Quran \& Tafsir

Volume 5, No. 1, 2020

P-ISSN: 2548-7248

E-ISSN: 2715-5692

Homepage : http://journal.iaimsinjai.ac.id/indeks.php/al-mubarak

ilmu maupun aspek 'murni-terapan', dan ketiga,teknologi merupakan keahlian yang terkait dengan realitas kehidupan sehari-hari (Tjahyadi, S, 2003:153). Definisi diatas dapat menunjukkan bahwa tekhnologi merupakan hasil olahan ilmu pengetahuan yang meliputi kemampuan teknik, keahlian, kreatifitas dan ciptaan manusia yang menunjang kebutuhan manusia tersebut secara praktis dan berdaya guna dalam kehidupannya.

\subsection{Iptek; Selalu, antara Kebutuhan dan Tantangan}

Melalui tekhnologi aktifitas dan kebutuhan manusia dapat dengan mudah dilakukan hingga mencapai hasil maksimal yang diinginkan. Baik dari segi komunikasi informasi dan pelayanan yang tidak lagi menguras waktu dan tenaga manusia untuk melakukannya. Akses infomasi yang demikian cepat (internet: sumber informasi utama manusia masa kini) dengan hadirnya fasilitas internet telah memberikan peluang dan strategi bagi siapa saja untuk mengaksesnya baik yang ada dalam situs-situs jejaring sosial mengarahkan manusia untuk beradu pemikiran. Dalam konteks ini Iptek jelas-jelas diperlukan dan menjadi kebutuhan penting manusia, dalam kehidupan jangka panjang Iptek berperan vital melansungkan eksistensi manusia modern, akibatnya ketergantungan menjadi bahkan inovasi tiada henti menjadi kondisi real untuk melanggengkan peradaban.

Di sisi lain perkembangan Iptek yang demikian pesat ini, menyebabkan manusia larut dan terlena dalam buaian teknologi itu yang tanpa disadari, peran dan terjangan pola budaya kapitalistik dan hedonis yang dipelopori Barat (Yahudi dan Nasrani) membawa pada pola hidup individualis, pragmatis, materialis, dan sekuler hingga menyebabkan manusia lupa akan eksistensinya, baik eksistensi berketuhanan dan eksistensi kemanusiaan pun kian tercerabut dari hakikat dasarnya sehingga tidak akan membawa manusia pada kemaslahatan hidup. Waktu yang nyaris hilang bagi ummat manusia-khususnya ummat Islam dengan larutnya pada kesibukan Iptek dan menjauhkan diri dari kegiatan-kegiatan spiritual, dan nilai-nilai ketauhidan hingga berimplikasi pada redupnya akhlak, imam dan keislaman. Kecenderungan lain manusia mengalami kegersangan jiwa yang nyaris hilang dan tanpa kendali, menghilangkan bentuk kesalehan spiritual 


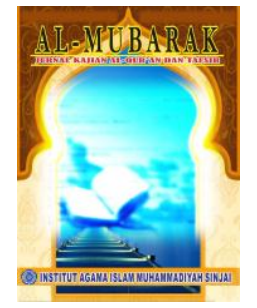

AI-MUBARAK

Jurnal Kajian Al-Quran \& Tafsir

Volume 5, No. 1, 2020

P-ISSN: 2548-7248

E-ISSN: 2715-5692

Homepage : http://journal.iaimsinjai.ac.id/indeks.php/al-mubarak

dan mendewakan piranti soft dan hard, hingga mengalami kebingungan dalam pusaran teknologi.

Krisis multidimensi demikian membawa perubahan signifikasi yakni hilangnya kendali nilai-nilai moral Ketuhanan dan agama. Krisis ekologis, http://www.al-shia.org, misalnya: berbagai bencana alam akhir-akhir ini: tsunami, gempa dan kacaunya iklim dan cuaca dunia akibat pemanasan global yang disebabkan tingginya polusi industri di negara-negara maju; Wabah penyakit Virus Corona Desease-19 (Covid-19) melanda China dan hampir semua negara; kehancuran ekosistem laut dan pantai akibat polusi yang diihasilkan oleh pertambangan mineral emas, perak dan tembaga, seperti disejumlah negara. Kebocoran reaktor Nuklir di Chernobil, Rusia, dan di India, dll. Krisis Ekonomi dan politik yang terjadi di banyak negara berkembang dan negara miskin, terjadi akibat ketidakadilan dan 'penjajahan' (neo-imperialisme) negara-negara maju yang menguasai perekonomian dunia dan Iptek modern. Demikianlah yang terjadi maka Iptek dalam kondisi ini sulit membawa manusia pada jalan kesejahteraan, kedamaian. Tantangan demikian nyata jika Iptek memiliki dua sisi yang berbeda, disatu sisi membawa kemaslahatan umat manusian dan disisi lain membawa konsekwensi negatif bagi eksistensi manusia.

\subsection{Iptek Modern dalam Ajaran Islam}

Peradaban Islam sangat berbeda dengan Yunani, Romawi dan Byzantium dalam memandang teknologi. Para cendekiawan muslim diera kekhalifahan menganggap teknologi sebagai sebuah cabang ilmu pengetahuan yang sah. Fakta itu terungkap berdasarkan pengamatan para sejarawan sains Barat di era modern terhadap sejarah sains di Abad Pertengahan. Demikian pula ajaran Islam ia tidak akan bertentangan dengan teori-teori pemikiran modern yang teratur dan lurus dan analisa-analisa yang teliti dan obyekitf.

Dalam pandangan Islam menurut hukum asalnya segala sesuatu itu adalah mubah termasuk segala apa yang disajikan oleh berbagai peradaban baik yang lama ataupun yang baru. Semua itu sebagaimana diajarkan oleh Islam tidak ada yang hukumnya haram kecuali jika terdapat nash atau dalil yang tegas dan pasti mengherankannya (Firmanto, T, 2013). Sebagai umat Islam penting lebih 


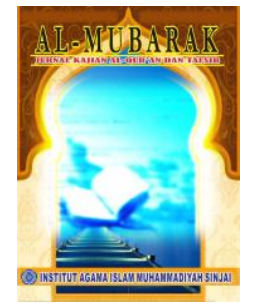

\section{Al-MUBARAK}

Jurnal Kajian Al-Quran \& Tafsir

Volume 5, No. 1, 2020

P-ISSN: 2548-7248

E-ISSN: 2715-5692

Homepage : http://journal.iaimsinjai.ac.id/indeks.php/al-mubarak

menyadari bahwa dasar-dasar filosofis untuk mengembangkan ilmu dan teknologi saat ini harus dikaji dan digali dalam Al-quran sebab kitab suci ini banyak mengupas keterangan-keterangan mengenai Iptek.

Al-Qur'an menuntun umat Islam untuk mengembangan kapasitas ilmiahnya terutama dalam upaya pengembangan Iptek. Manusia-umat Islam yang sadar akan eksistensinya dan sebagai insan yang memiliki naluri ingin serba tahu terhadap hal-hal yang dianggapnya masih misteri membuatnya terus berupaya membuka tabir ilmu pengetahuan. Jika dieksplorasi pandangan Al-Qur'an tentang ilmu pengetahuan dan tekhnologi ini, sebagai contoh yang membicarakan tentang fenomena alam, dan sekaligus memerintahkan manusia untuk memahaminya maka hal ini dapat ditelaah perintah Al-Qur'an yang terdapat dalam surat AlGhasyiyah ayat 17-20 "Maka Apakah mereka tidak memperhatikan unta bagaimana Dia diciptakan?, dan langit, bagaimana ia ditinggikan?, dan gununggunung bagaimana ia ditegakkan?, dan bumi bagaimana ia dihamparkan?. (QS. Al-Ghasyiyah [88]:17-20.

Penegasan Al-Qur'an tersebut umat Islam membuktikan kemampuan ilmiahnya dengan mengambil peran terhadap kemajuan Iptek, sebagaimana sejarah telah mencatat bahwa puncak kejayaan ilmu pengetahuan adalah berasal dari Islam hingga mengalami kemunduran lalu tradisi tersebut beralih ke dunia Barat (non Islam). Namun demikian hingga hari ini peranan ummat Islam terhadap kemajuan Iptek patut diapresiasi sebagai kemajuan yang luar biasa. Sebagai contoh keberhasilan dan keunggulan Negara Republik Islam Iran, Turki, Arab Saudi bahkan Indonesia dengan penduduk mayoritas Islam mengembangkan Iptek sehingga disegani oleh negara maju seperti Amerika dan sekutunya terkait tekhnologi yang dikembangkan. Ini sebagai bukti peranan Islam dalam kemajuan tekhnologi modern. Perkembangan kebudayaan Iran sebagai Negara Islam berkenaan dengan teknologi dan sains sungguh luar biasa, hasil penelitian dari Kanada menunjukkan 11 lebih cepat perkembangan sains dan teknologi di Iran jika dibandingkan dengan negara-negara lain. Pemaparan Naderin Manesh, Wakil Menteri Sains, Riset dan Teknologi Republik Islam Iran, perkembangan peradaban Islam yang terjadi ini dilandasi; Pertama, Ijtihad yang sungguh- 


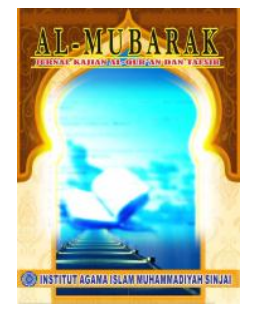

\section{Al-MUBARAK}

Jurnal Kajian Al-Quran \& Tafsir

Volume 5, No. 1, 2020

P-ISSN: 2548-7248

E-ISSN: 2715-5692

Homepage : http://journal.iaimsinjai.ac.id/indeks.php/al-mubarak

sungguh, kedisiplinan dan semangat yang tinggi dalam mencapai dan belajar ilmu pengetahuan. Kedua, Pandangan dunia yang benar. Tahap ini tidak akan tercapai. Ketiga, Semua yang melandasi itu kemandirian berfikir, tanpa tekanan dari yang lain dan negara manapun. (Ghifarie, I, 2013) http://www.uinsgd.ac.id/.

Menurut Rizky dalam (Prawiraningrat, A, 2013) peran Islam dalam perkembangan Iptek pada dasarnya ada 2 (dua), yaitu:

Menjadikan aqidah Islam sebagai paradigma pemikiran dan ilmu pengetahuan. Jadi, paradigma Islam, dan bukannya paradigma sekuler, yang seharusnya diambil oleh umat Islam dalam membangun struktur ilmu pengetahuan; (2) Menjadikan syariah Islam sebagai standar penggunaan ilmu pengetahuan. Jadi, syariah Islamlah, bukannya standar manfaat (utilitarianisme), yang seharusnya dijadikan tolok ukur umat Islam dalam mengaplikasikan iptek.

Berkaitan dengan peran agama Islam yang pertama, aqidah Islam sebagai dasar Iptek. Inilah peran pertama yang dimainkan Islam dalam Iptek, yaitu aqidah Islam harus dijadikan basis segala konsep dan aplikasi ilmu pengetahuan dan teknologi. Inilah paradigma Islam sebagaimana yang telah dibawa oleh Rasulullah SAW. Namun di sini perlu dipahami dengan seksama, bahwa ketika aqidah Islam dijadikan landasan Iptek, bukan berarti konsep-konsep Iptek harus bersumber dari Al-Qur`an dan Al-Hadits, tapi maksudnya adalah konsep Iptek harus distandardisasi benar salahnya dengan tolak ukur Al-Qur`an dan Al-Hadits dan tidak boleh bertentangan dengan keduanya. Maksud dari menjadikan aqidah Islam sebagai landasan Iptek bukanlah bahwa konsep Iptek wajib bersumber kepada AlQur`an dan Al-Hadits, tapi yang dimaksud, bahwa Iptek wajib berstandar pada Al-Qur`an dan Al-Hadits. Ringkasnya, Al-Qur`an dan Al-Hadits adalah standar (miqyas) ilmu pengetahuan dan teknologi, dan bukannya sumber (mashdar) Iptek. Artinya, apa pun konsep yang dikembangkan, harus sesuai dengan Al-Qur`an dan Al-Hadits.

Peran kedua agama Islam dalam perkembangan Iptek adalah bahwa syariah Islam harus dijadikan standar pemanfaatan Iptek. Ketentuan halal-haram (hukumhukum syariah Islam) wajib dijadikan tolok ukur dalam pemanfaatan Iptek, bagaimana pun juga bentuknya. Iptek yang boleh dimanfaatkan, adalah yang telah 


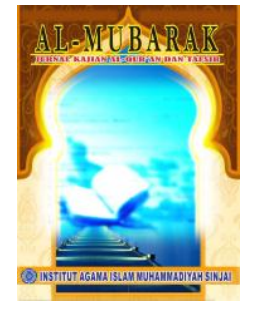

\section{Al-MUBARAK}

Jurnal Kajian Al-Quran \& Tafsir

Volume 5, No. 1, 2020

P-ISSN: 2548-7248

E-ISSN: 2715-5692

Homepage : http://journal.iaimsinjai.ac.id/indeks.php/al-mubarak

dihalalkan oleh syariah Islam. Sedangkan Iptek yang tidak boleh dimanfaatkan, adalah yang telah diharamkan syariah Islam. Keharusan tolok ukur syariah ini didasarkan pada banyak ayat dan juga hadits yang mewajibkan umat Islam menyesuaikan perbuatannya (termasuk menggunakan Iptek) dengan ketentuan hukum Allah dan Rasul-Nya. Jika kedua peran tersebut dijalankan oleh ummat Islam dengan semaksimal mungkin maka kemaslahatan ummat akan terwujud diera modern sekarang ini. Kemaslahatan ummat dengan hadirnya Iptek adalah cita-cita Islam dan dambaan seluruh ummat Islam. Kedamaian, ketentraman dan kesejahteraan hidup manusia dalam segala dimensi kehidupannya adalah wujud yang dilandasi oleh nilai-nilai moralitas agama.

\subsection{Al-Qur'an sebagai Sumber Inspirasi Iptek}

Salah satu ciri yang membedakan Islam dengan yang lain adalah penekanannya terhadap masalah ilmu. Al-qur'an, sebagai sumber utama ajaran Islam, telah memberikan landasan yang kuat bagi umat islam dalam mengembangkan ilmu pengetahuan dan teknologi. Al-qur'an dan As Sunnah mengajak kaum muslimin untuk mencari dan mendapatkan ilmu dan kearifan, serta menempatkan orang-orang yang berpengetahuan pada derajat yang tinggi, (Nazaruddin, 2013).

Sumber utama ilmu pengetahaun adalah Allah SWT karena Allah yang menciptakan ilmu pengetahuan tersebut. Dialah yang menurunkan ilmu pengetahuan melalui ayat ilahiyahnya dan insaniyahnya. Sebagai epistemology ilmu pengetahuan, maka Al-Qur'an sebagai ayat ilahiyah dan hadis adalah basis perumusan teori dalam tradisi penelitian umat Islam, namun sumber pengetahuan lain selain sumber ilahiyah tersebut terdapat pula diri insaniyah atau potensipotensi manusia. Potensi manusia untuk berpikir untuk menemukan ilmu pengetahuan baik melalui dirinya sendiri maupun alam sekitarnya.

Menurut (Kuntowijoyo, 2004:12) paradigma Al-Qur'an berarti suatu konstruk pengetahuan yang memungkinkan kita memahami realitas sebagaimana Al-Qur'an memahaminya. Konstruk ilmu pengetahuan itu dibangun oleh AlQur'an pertama-tama dengan tujuan agar kita memiliki "hikmah" yang atas dasar itu dapat dibentuk prilaku yang sejalan dengan nilai-nilai normatif Al-Qur'an, 


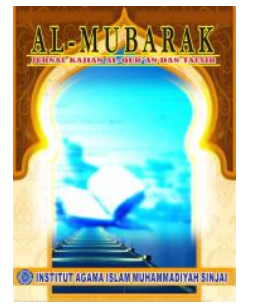

\section{Al-MUBARAK}

Jurnal Kajian Al-Quran \& Tafsir

Volume 5, No. 1, 2020

P-ISSN: 2548-7248

E-ISSN: 2715-5692

Homepage : http://journal.iaimsinjai.ac.id/indeks.php/al-mubarak

baik pada level moral maupun sosial. Tetapi rupanya, konstruk pengetahuan itu juga memungkinkan kita merumuskan desain-desain mengenai system pendidikan Islam, termasuk dalam hal system ilmu pengetahuannya. Jadi, disamping memberikan gambaran aksiologis, paradigma Al-Qur'an juga dapat berfungsi untuk memberikan wawasan epistemologis. Merujuk beberapa ayat Al-Qur'an menjelaskan yaitu diantaranya

a. Surat Al-Alaq ayat 1-5:

"Bacalah dengan (menyebut) nama Tuhan-mu Yang menciptakan. Dia telah menciptakan manusia dari segumpal darah. Bacalah, dan Tuhanmulah Yang Maha Pemurah, Yang mengajar (manusia) dengan perantaraan kalam. Dia mengajarkan kepada manusia apa yang tidak diketahuinya." (QS.Al-Alaq [96]:1-5.

Ayat diatas sebagai ayat yang pertama kali turun yang diterima oleh Rasulullah Muhammad SAW di Gua Hira, kata "Iqraa” yang berarti bacalah, perintah membaca tersebut sebagai acuan dasar belajar. Kendati membaca disini diperuntukkan "menyebut nama Tuhan-Allah SWT", namun Al-Qur'an itu sendiri menghendaki membaca apa saja selama membaca itu dalam konteks makro, bermanfaat dan berskala kemanusiaan. Kata "bacalah" disini dapat dimaknai pula sebagai perintah "telitilah, amatilah, dalamilah. Meneliti dan mengamati apa saja baik kekuasaan Allah-tanda-tanda alam, ilmu yang diturungkan baik yang tersurat maupun yang tersirat. Hal ini mencakup secara umum yang berkaitan kegiatan manusia untuk mengetahui segala sesuatu yang dapat membawa manfaat dan kemaslahatan manusia umumnya dan ummat Islam khususnya.

Selanjutnya, dari wahyu pertama Al-Qur'an diperoleh isyarat bahwa ada dua cara perolehan dan pengembangan ilmu, yaitu Allah swt mengajar dengan pena yang telah diketahui manusia lain sebelumnya, dan mengajar manusia (tanpa pena) yang belum diketahuinya. Cara pertama adalah mengajar dengan alat atas dasar usaha manusia, sedangkan cara kedua mengajar tanpa alat dan tanpa usaha manusia. Walaupun berbeda, keduanya berasal dari satu sumber, yaitu Allah SWT. Manusia, menurut Al-Qur'an memiliki potensi untuk meraih ilmu dan mengembangkan dan menikmati manfaatnya dengan izin Allah SWT. Karena itu, 


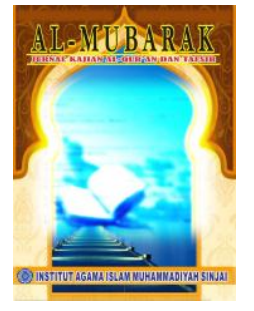

\section{Al-MUBARAK}

Jurnal Kajian Al-Quran \& Tafsir

Volume 5, No. 1, 2020

P-ISSN: 2548-7248

E-ISSN: 2715-5692

Homepage : http://journal.iaimsinjai.ac.id/indeks.php/al-mubarak

bertebaran ayat yang memerintahkan manusia menempuh berbagai cara untuk mewujudkan hal tersebut. Berkali-kali Al-Qur'an menunjukkan betapa tingginya kedudukan orang-orang yang berpengetahuan. Al-Qur'an memerintahkan manusia untuk terus berupaya meningkatkan kemampuan ilmiahnya, karena manusia memiliki naluri selalu haus akan (rasa ingin tahu) apa saja yang ada di sekitarnya. Hal ini dapat menjadi pemicu manusia untuk terus mengembangkan teknologi dengan memanfaatkan anugerah Allah swt yang dilimpahkan kepadanya (Nazaruddin, 2013).

b. Surat Al-Anbiya ayat 80 mengemukakan bahwa:

"Telah kami ajarkan kepada Daud membuat baju besi untuk kamu guna memelihara diri dalam peperanganmu." (QS.Al.Anbiya [21] : 80.

Dari ayat tersebut diatas jelas bahwa manusia telah diperintahkan membuat sarana tekhnologi untuk menunjang aktifitas dan kelansungan hidupnya. Maka tidak heran jika kembali merefiew sejarah yang sebelum abad ke 10 Masehi manusia-manusia muslim (pemikir-pemikir muslim) telah mampu mempelihatkan tekhnologi dan produktif dalam upaya pengembangan ilmu pengetahuan dan tekhnologi. Keunggulan ummat Islam dalam ilmu pengetahuan dan tekhnologi masa lalu sangat mempengaruhi kehidupan dan kemajuan ilmu pengetahuan hingga masa-masa kejayaan Islam hingga dibidang ini mengalami kemunduran akhirnya ilmu pengetahuan dan tekhnologi ummat Islam itu beralih ke dunia barat hingga era modern ini barat masih menjadi pengendali utama tekhnologi.

c. Surat Yunus ayat 101:

"Katakanlah, "Perhatikanlah apa yang ada di langit dan di bumi!. Tidaklah bermanfat tanda kekuasaan Allah dan asul-rasul yang memberi peringatan bagi orang-orang yang tidak beriman " (QS.Yunus [10]:101.

d. Surat Thaahaa ayat 114:

"Maka Maha Tinggi Allah Raja Yang sebenar-benarnya, dan janganlah kamu tergesa-gesa membaca Al Qur'an sebelum disempurnakan mewahyukannya kepadamu, dan katkanlah:"Ya Tuhanku, tambahkanlah kepadaku Ilmu Pengetahuan. (QS. Thaaha [20]:114.

Makna ayat-ayat di atas sangat jelas bahwa manusia dituntut untuk memahami realita cipataan Allah SWT sekaligus menjadikan kitab suci Al-Qur'an 


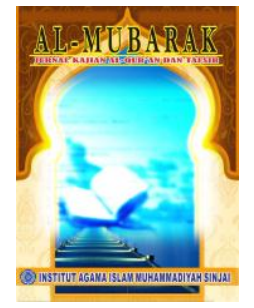

AI-MUBARAK

Jurmal Kajian Al-Quran \& Tafsir

Volume 5, No. 1, 2020

P-ISSN: 2548-7248

E-ISSN: 2715-5692

Homepage : http://journal.iaimsinjai.ac.id/indeks.php/al-mubarak

sebagai sumber Iptek. Karena agama Islam mengarahkan umatnya dalam mengembangkan ilmu pengetahuan maupun tekhnologi berada pada koridor yang dipersyaratkan.

\subsection{Mengingatkan Gagasan Ilmuan tentang Islamisasi Iptek Modern}

Islamisasi sebagai gerakan intelektual internasional pertama kali dimunculkan oleh Isma'il Raji Al-Faruqi dari Lembaga Pemikiran Islam Internasional (International Institute of Islamic Thought) di Amerika Serikat menjelang 1980-an. Gagasan Islamisasi ilmu pengetahuan sudah dicetuskan sebelumnya oleh Naquib Al-attas dari Malaysia. Islamisasi ilmu pengetahuan dijelaskan oleh al-Attas sebagai pembebasan manusia dari tradisi magis, mitologis, animistis, kultur-nasional (yang bertentangan dengan Islam) dan dari belenggu paham sekuler. Selain itu, pembebasan dari kontrol dorongan fisik yang cenderung sekuler dan tidak adil terhadap hakikat diri atau jiwanya, sebab manusia dalam wujud fisiknya cenderung lupa terhadap hakikat dirinya yang sebenarnya, dan berbuat tidak adil terhadapnya, (Daud Wan, NMW, 1998: 345).

Menurut (Kuntowijoyo, 2004:8) islamisasi pengetahuan berusaha supaya ummat Islam tidak begitu saja meniru metode-metode dari luar yang mengembalikan pengetahuan pada pusatnya, yaitu tauhid. Dari tauhid akan ada tiga macam kesatuan, yaitu kesatuan pengetahuan, kesatuan kehidupan, dan kesatuan sejarah. Selama ummat Islam tidak mempunyai metodologi sendiri, ummat akan selalu dalam bahaya. Kesatuan pengetahuan artinya pengetahuan harus menuju kepada kebenaran yang satu. Kesatuan hidup berarti hapusnya perbedaan antara ilmu yang sarat nilai dengan ilmu yang bebas nilai. Kesatuan sejarah artinya pengetahuan harus mengabdi pada ummat dan pada manusia.

Catatan tentang pentingnya Islamisasi Ilmu Pengetahuan yakni; Pertama, Islamisasi ilmu pengetahuan lahir sebagai koreksi dari ilmu-ilmu modern yang dihasilkan oleh dunia Barat yang cenderung bebas nilai dari tuntunan wahyu. Secara ontologis, Islamisasi ilmu pengetahuan memandang bahwa realitas alam semesta, realitas sosial dan historis ada hukum-hukum yang mengatur dan hukum itu adalah ciptaan Tuhan. Kedua, Islamisasi ilmu pengetahuan dalam tataran epistimologinya mengkaji ayat-ayat al-Qur'an karena sebagian ayat al-Qur'an 


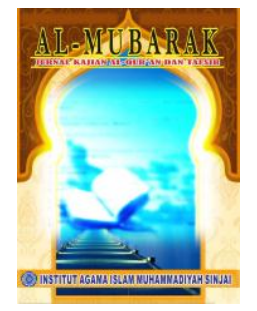

AI-MUBARAK

Jurnal Kajian Al-Quran \& Tafsir

Volume 5, No. 1, 2020

P-ISSN: 2548-7248

E-ISSN: 2715-5692

Homepage : http://journal.iaimsinjai.ac.id/indeks.php/al-mubarak

memasuki wilayah kajian empiris dan historis sehingga kebenaran pernyataannya terbuka untuk dibuktikan dan dihadapkan dengan metodologi keilmuan. Ketiga, Islamisasi ilmu pengetahuan secara aksiologi memandang bahwa ilmu pengetahuan itu sarat dengan nilai-nilai moral (moral value) dengan kata lain ilmu itu tidak netral nilai melainkan dalam ilmu pengetahuan itu terkandung nilai-nilai luhur berdasarkan ajaran Islam yang mengkristal pada akar-akar Ilahi, (Alfatih, 2013).

Adapun tujuan Islamisasi pengetahuan ini menurut Al-Faruqi, yaitu; Pertama, Penguasaan disiplin ilmu modern. Kedua, Penguasaan warisan Islam. Ketiga, Penentuan relevansi khusus Islam bagi setiap bidang pengetahuan modern. Keempat, Pencarian cara-cara untuk menciptakan perpaduan kreatif antara warisan Islam dan pengetahuan modern (melalui survey masalah umat Islam dan umat manusia seluruhnya). Kelima, Pengarahan pemikiran Islam ke jalan yang menuntunnya menuju pemenuhan pola Ilahiyah dari Allah. Keenam, Realisasi praktis Islamisasi pengetahuan melalui: penulisan kembali disiplin ilmu modern ke dalam kerangka Islam dan menyebarkan pengetahuan Islam, http://www.al-shia.org.

Fungsi Iptek pada hakekatnya membawa kemaslahatan umat manusia-umat Islam, dan pada sisi lain membawa kehancuran bagi ummat manusia tanpa objek, ruang dan waktu, maka penting dilakukan penelahan lebih mendalam terutama bagi para intelektual Islam baik dalam bentuk penggunaan dan kemanfaatannya. Islam sebagai agama yang suci memberikan ruang terbuka bagi manusia untuk melakukan strategi pengembangan dalam dimensi kehidupan manusia itu sendiri terutama Iptek sepanjang dalam aplikatif dapat membawa manfaat dan tidak menimbulkan kemudaratan. Disinilah pentingnya ummat Islam memposisikan diri dalam mengambil peran untuk mengarahkan Iptek dengan semaksimal mungkin pada tatanan kemaslahatan ummat manusia. Kajian dan penerapan-penerapan teknologi sebagai aksiologi ilmu pengetahuan perlu kontrol sesuai batas-batas nilai agama dan kaidah syariah-Islam. Bentuk tindakan yang demikian ini sebagai salah satu bentuk strategi Islamisasi Iptek. 


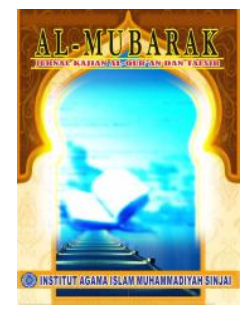

AI-MUBARAK

Jurnal Kajian Al-Quran \& Tafsir

Volume 5, No. 1, 2020

P-ISSN: 2548-7248

E-ISSN: 2715-5692

Homepage : http://journal.iaimsinjai.ac.id/indeks.php/al-mubarak

Pengetahuan sebagai kebudayaan dimanfaatkan sebagai berlakungan suatu

ilmu pengetahuan dalam masyarakat kebudayaan. Dalam dunia Barat potret egoistik dan individualis orientalis menganggap ilmu pengetahuan tidak berhubungan dengan hakikat murni dari Islam, bentuk eksperimen yang dilakukan kadang berlebihan dan mengklaim sebagai kebenaran dan agama tidak disangkutpautkan dengan ilmu pengetahuan yang dikembangkan karena inilah misi sekularisme dan propoganda. Pada posisi ini umat Islam penting lebih menyadari atas kekhawatiran terlebih perkembangan global kian maju dengan pesat.

Dalam bentuk ilmu pengetahuan dan kesenian ada tentang dari objentiveveriable sampai yang ke subjective. Menurut Arthur Koestler mengemukakan rentang itu ialah, Kimia, Biokimia, Biologi, Kedokteran, Psikologi, Antropologi, Sejarah, Biografi, Novel, Epik dan Lirik. Untuk ilmu yang betul-betul objektif kiranya sangat bergantung pada niat individu, maka niat itulah yang perlu diislamisasi, dan bukan ilmunya (Kuntowijoyo, 2004:9). Disisi lain guna terwujudnya ilmu pengetahuan guna kemasalahatan, ilmu juga diposisikan pada lingkaran Islamisasi dalam artian implementasi ilmu mestinya mengarah pada kemaslahatan dan kebahagiaan manusia sesuai konteks nilai-nilai keislaman. Dengan demikian memposisikan Iptek modern secara tepat penting bagi kita umat Islam guna tetap mengcounter pengaruh sekularisasi Barat yang bebas nilai.

Jika merujuk para ilmuan-ilmuan Islam terkenal bahkan ilmuan barat sepanjang sejarah baik dalam proses pengkajiannya terhadap Iptek tidak hanya memiliki komitmen teguh untuk membawa hasil pemikirannya pada arah tatanan kehidupan manusia yang lebih bermanfaat dan berperadaban, namun memiliki pula landasan filsafat ketuhanan dan nilai-nilai fundamental agama yang mumpuni, sebagaimana contoh ungkapan terkenalnya dari Albert Einstein itu. Maka dengan demikian antara ilmu dan agama tidak dapat terpisahkan. Karna sumber utama ilmu pengetahuan dapat melalui teks-teks keagamaan yang dalam konteks ini nash Al-Qur'an dan Hadis-hadis Nabi SAW yang sahih. Berdasar gagasan diatas telah lebih dari satu dekade terakhir, (Muhaimin, 2006:61-65) telah menawarkan beberapa model pengembangan Iptek yaitu: 


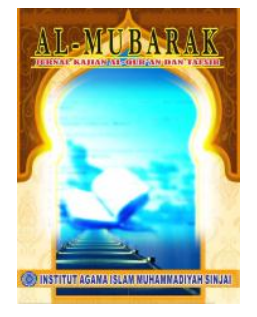

AI-MUBARAK

Jurnal Kajian Al-Quran \& Tafsir

Volume 5, No. 1, 2020

P-ISSN: 2548-7248

E-ISSN: 2715-5692

Homepage : http://journal.iaimsinjai.ac.id/indeks.php/al-mubarak

Pertama,Model purifikasi, pada model ini diartikan sebagai pembersihan

dan penyucian, yakni dengan berusaha menyelenggarakan pengkudusan ilmu pengetahuan agar sesuai dan sejalan dengan nilai dan norma islam. Seperti halnya yang telah digagas oleh Al-Faruqi dan Al-Attas, yang telah merekomendasikan islamisasi ilmu pengetahuan dengan: Penguasaan khasanan ilmu pengetahuan muslim, penguasaan khasanah pengetahuan masa kini, identifikasi kekurangan ilmu pengetahuan itu dalam kaitannya dengan ideal Islam, dan rekontruksi ilmuilmu itu sehingga menjadi suatu paduan yang selaras dengan wawasan dan ideal Islam.

Kedua, Model modernisasi Islam, yaitu dengan membuka mata dunia Islam untuk cenderung mengembangkan pesan Islam dalam konteks perubahan sosial dan perkembangan ilmu pengetahuan dan teknologi. Serta melakukan liberalisasi pandangan yang adaftif terhadap kemajuan zaman tanpa harus meninggalkan sikap kritis terhadap unsur negatif dari proses modernisasi, sehingga ia lebih menampilkan kelenturan dan keterbukaan dalam menanggapi dunia yang plural dan terus berubah. Dengan kata lain bersikap modern berarti bersikap lentur, terbuka, ilmiah, rasional, progresif dan dinamis, serta tanpa segan melakukan transformasi, akomodasi bahkan adopsi terhadap pemikiran dan temuan dari ilmu pengetahuan dan teknologi.

Ketiga, Model neo-modernis, yaitu berupaya memahami ajaran-ajaran dan nilai mendasar yang terkandung dalam Al-Qur'an dan sunnah dengan mengikutsertakan dan mempertimbangkan khasanah intelektual muslim klasik serta mencermati kesulitan-kesulitan dan kemudahan-kemudahan yang ditawarkan oleh dunia ilmu pengetahuan dan teknologi modern.

Pandangan diatas sejalan yang dikemukakan (Ali, K. M. U. 2016:13) jika pada dasarnya Islam tidak menghambat kemajuan Iptek asalkan objektif dan tidak bertentangan dengan dasar Al-Quran, sehingga peran Islam dalam perkembangan iptek yakni tidak menjadikan aqidah Islam sebagai paradigma ilmu pengetahuan, dan menjadikan syariah Islam (yang lahir dari aqidah Islam) sebagai standar bagi pemanfaatan iptek dalam kehidupan sehari-hari. 


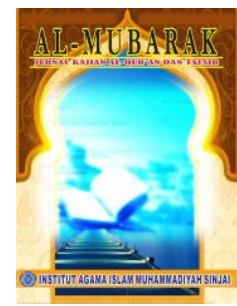

Al-MUBARAK

Jurnal Kajian Al-Quran \& Tafsir

Volume 5, No. 1, 2020

P-ISSN: 2548-7248

E-ISSN: 2715-5692

Homepage : http://journal.iaimsinjai.ac.id/indeks.php/al-mubarak

\subsection{Khazanah Tptek dan Implikasinya dalam Pendidikan Islam}

Menyikapi gelombang besar abad 21 perubahan tatanan teknologi modern yang menjangkau berbagai aspek kehidupan manusia saat ini termasuk di lembaga pendidikan kita, penting mempropagandakan kembali khazanah Iptek modern yang menyeimbangkan nilai-nilai fundamendal spiritual dan budaya dalam berbagai aspek kehidupan seperti dakwah, pendidikan, politik dsb. Menurut alAttas untuk melakukan islamisasi ilmu pengetahuan perlu melibatkan dua proses yang saling berhubungan. Pertama ialah melakukan proses pemisahan elemen dan konsep kunci yang membentuk kebudayaan dan peradaban Barat, dan Kedua, memasukan elemen Islam dan konsep kunci ke dalam setiap cabang ilmu pengetahuan masa kini yang relevan (Daud Wan, NMW, 1998:341). Pandangan ini mengisyaratkan aspek-aspek kehidupan yang berhubungan pengembangan ilmu pengetahuan penting mengintegrasikan nilai-nilai fundamental dan spiritual kedalam proses ini.

Zainiyati, H. S. (2015) menawarkan upaya integrasi sains dengan ilmu agama jangka panjang di lembaga pendidikan Islam seperti UIN melalui corak berpikir gagasan Sardar dan Al-Faruqi. Dalam perspektif filsafat pendidikan Islam juga penting menempatkan ilmu pengetahuan dibangun dalam koridor tauhid yang bersasaran pada potensi jasmani dan ruhani yang melahirkan generasi terdidik dan khalifah yang akan menggunakan akal dan kepercayaan pada wahyu Al-Quran, Daulay, A. F. (2013). Oleh karena itu ummat Islam dengan memahami agamanya akan dapat memotivasi untuk menekuni sains dan teknologi melalui landasan nilai-nilai Al-Quran, (Fakhri, J, 2010).

Iplikasinya dalam kontek pendidikan Islam maka langkah upaya menyikapi perkembangan Iptek modern dan masa kini yaitu; (1). Dalam pendidikan pentingnya dilakukan pengajaran dan pembelajaran dengan mengintegrasikan dan menyelaraskan antara Iptek dengan Imtak. (2). Pentingnya memperkenalkan atau mensosialisasikan dampak positif dan negative serta pengaruh dari tekhnologi baik pada siswa ditiap tingkatan dan satuan pendidikan, hingga masyarakat luas. (3). Pentingnya mengintegrasikan nilai-nilai akhlak dan keagamaan pada tiap kurikulum materi pengajaran ilmu terapan di sekolah-sekolah. (4). Pendidikan 


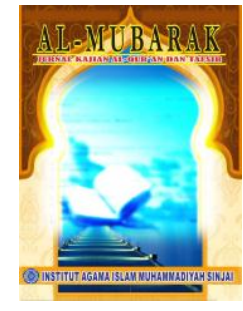

AI-MUBARAK

Jurnal Kajian Al-Quran \& Tafsir

Volume 5, No. 1, 2020

P-ISSN: 2548-7248

E-ISSN: 2715-5692

Homepage : http://journal.iaimsinjai.ac.id/indeks.php/al-mubarak

nilai (baik nilai moralitas Islam dan nilai karakter budaya lokal) sebagai aspek pembentukan kepribadian yang berkarakter dalam menghadapi dinamika perkembangan Iptek. (5). Pengembangan Iptek yang dalam pandangan Islam-manusia sebagai khalifah, perlunya dipahami bahwa tujuan dari Iptek tersebut adalah untuk kemakmuran manusia dimuka bumi atau sebagai rahmatan lilalamin. (6). Pentingnya penelaahan lebih mendalam makna dan hakekat Iptek dari (ayat) Al-Qur'an sebagai dasar teori dan sumber inspirasi pemikiran dan pengembangan Iptek modern, dimana Al-Qur'an sebagai sumber otentik yang tersurat dan tersirat yang dapat dipadukan dengan sumber lain seperti buku dan internet (Junaedi, 2013). Maka insan dan generasi Islam telah seyogyanya menuntut ilmu pengetahuan dan mengikuti pola perkembangan serta mengambil peran pengembangan tekhnologi yang berlandaskan pada iman, nilai-nilai keislaman dan budaya.(7). Berkembangnya sebuah teknologi adalah bagian dari kebijakan para pemimpin negeri (penguasa, pemegang kebijakan) yang sangat strategis dan berpengaruh, maka dengan demikian hendaknya menyadari dan memberikan peluang kebijakan pengembangan tekhnologi yang berbasis pada daya manfaat serta batas kebutuhan masyarakat yang berlandaskan pada nilai-nilai keagamaan-(keislaman) dan kemanusiaan

\section{Simpulan}

Epistemologis Islam telah memberikan batasan-batasan nilai dalam menata dan mengembangkan Ilmu pengetahuan dan teknologi termasuk implementasinya dalam kehidupan. Islamisasi Iptek yang telah diprakarsai ilmuan muslim modern patut selalu dipromosikan mengingat teknologi diorientasikan pada cara-cara praktis dan kurang membawa kemaslahatan dan kebahagiaan manusia. Pentingnya Iptek dalam ajaran Islam sebagai langkah mengantarkan manusia menuju pada pola kehidupan yang damai, dalam aspek aksiologi memandang ilmu pengetahuan sarat dengan nilai-nilai moral (moral value) dengan kata lain ilmu itu tidak netral nilai melainkan dalam ilmu pengetahuan itu terkandung nilai-nilai luhur berdasarkan ajaran Islam yang mengkristal pada akar-akar Ilahiyah. Oleh karena itu pengembangan Iptek hendaknya tetap menyelaraskan pada asas-asas dan nilainilai ajaran (teologis) Islam. Kesadaran akan dikembangkannya Iptek sebagai 


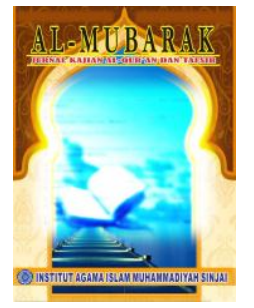

\section{Al-MUBARAK}

Jurnal Kajian Al-Quran \& Tafsir

Volume 5, No. 1, 2020

P-ISSN: 2548-7248

E-ISSN: 2715-5692

Homepage : http://journal.iaimsinjai.ac.id/indeks.php/al-mubarak

rahmatan lilatamin. Disinilah pentingnya manusia memilah dan memilih pengembangan ilmu pengetahuan dan penggunaan tekhnologi sesuai kapasitas dan kebutuhannya.

\section{Daftar Pustaka}

Alfatih, Sekularisasi dan Islamisasi Ilmu, dalam Website: http://alfatihberkah.blogspot.com /2013/01/sekularisasi-dan-islamisasiilmu. html. diakses, 22 Maret 2013. Pukul 15.00. WIB.

Ali, K. M. U. (2016). Integritas Pendidikan Agama Islam Terhadap Ilmu Pengetahuan dan Teknologi. Tadrib, 2(1).

Alwi, M. (2017). Islamisasi Ilmu Pengetahuan Kontribusi dalam Mengatasi Krisis Masyarakat Modern, Inspiratif Pendidikan, 6(2).

Fakhri, J, (2010). Sains dan Teknologi dalam Al-Qur'an dan Implikasinya dalam Pembelajaran, Ta'dib, 15(1), Juni.

Dwijo, Al. (2016). Pengembangan Iptek dalam Tinjauan Hukum Islam. Jurnal Pendidikan Agama Islam (Journal of Islamic Education Studies). 2(144). 10.15642/jpai.2014.2.1.

Daulay, A. F. (2013). Islamisasi Ilmu Pengetahuan: Perspektif Filsafat Pendidikan Islam. Journal Analytica Islamica, 2(1).

Departemen Agama RI, (2009).Al-Qur'an dan Terjemah-Nya, Bandung: Sigma Examedia Arkanleema.

Fahreena, Islamisasi Ilmu Pengetahuan dan Tekhnologi, dalam Website, http://fahreena. wordpress.com/2010/07/02/islamisasi-ilmu-pengetahuandan-teknologi/,diakses, 20 Maret, 2019, pukul 13.20 WIB.

Firmanto, Taufik, Islam dan Tekhnologi, dalam Website: http://humaniora. kompasiana.com /agama /2010/11/15/3/319311/islam-dan-teknologi.html,

Ghifarie, Ibn, Revolusi Sains dan Tekhnologi untuk Kemajuan Islam, dalam website: http://www.uinsgd.ac.id/front/detail/berita/revolusi-sains-danteknologi-untuk-kemajuan-islam, diakses, 20 Maret, 2019, pukul 13.00 WIB.

Http://www.al-shia.org/html/id/books/001/index.html, Iptek dan Peradaban Islam. diakses pada Tanggal 20 Maret 2019, pukul 16.00 WIB.

Ihsan Fuad, A, H, (2011). Filsafat Ilmu, Jakarta: Rineka Cipta. 


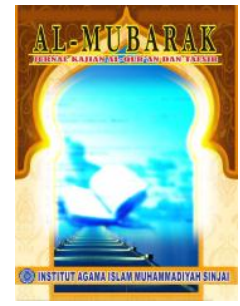

\section{Al-MUBARAK}

Jurnal Kajian Al-Quran \& Tafsir

Volume 5, No. 1, 2020

P-ISSN: 2548-7248

E-ISSN: 2715-5692

Homepage : http://journal.iaimsinjai.ac.id/indeks.php/al-mubarak

Junaedi, Ilmu Pengetahuan dan Tekhnologi, dalam Website: http: //edijunaedipoenya. blogspot.com/2009/01 /ilmu-pengetahuan-danteknologi-dalam.html, diakses, 19 Maret 2019, Pukul 17.15 WIB.

Kuntowijoyo, (2004).Islam Sebagai Ilmu, (Epistemologi, Metodologi dan Etika), Jakarta: PT.Mizan Publika.

Marsuki, (1995). Studi Awal Tentang Gagasan Islamisasi Ilmu-Ilmu Sosial, Jurnal Cakrawala Pendidikan, (2) XIV, Juli.

Muhaimin, (2006). Nuansa Baru Pendidikan Islam, Mengurai Benang Kusut Dunia Pendidikan, Jakarta : PT. Raja Grafindo Persada.

Nazaruddin, Ilmu Pengetahuan dalam Perspektif Islam, dalam website: http://kepribangkit. com/2013/01/ilmu-pengetahuan-dalam-persepektifislam/. diakses, 19 Maret 2019, Pukul 21.00 WIB.

Nizar, Syamsul, dan Ramayulis, 2009.Filsafat Pendidikan Islam, Telaah Sistem Pendidikan dan Pemikiran Para Tokohnya, Jakarta: Kalam Mulia.

Prawiraningrat, Alpiadi, Peran Islam dalam Perkembangan Ilmu, dalam Website: http://alpiadiprawiraningrat.blogspot.com/2012/09/peran-islam-dalamperkembangan-ilmu.html, diakses, 19 Maret, 2019, pukul 17.30 WIB.

Retnoningsih, Ana, dan Suharso, 2011.Kamus Besar Bahasa Indonesia, Edisi Lux, Semarang: CV. Widia Karya.

Siregar, Maragustam, (2013). Hand Out Perkuliahan Filsafat Pendidikan Islam, (dalam Power Point).

Tjaya, Hidya, Thomas, (2002). Kosmos Tanda Keagungan Allah, (Refleksi Menurut Louis Bouyer), Yogyakarta: Kanisius.

Wan Mohd Nor Wan Daud, The Educational Philosophy and Practice of Syed Muhammad Naquib al-Attas, diterjemahkan oleh Hamid Fahmy dkk, 1998. Filsafatdan Praktik Pendidikan Islam Syed M. Naquib al-Attas, Bandung: Mizan.

Zainiyati, H. S. (2015).Islamisasi Ilmu Pengetahuan (Sains) Sebagai Upaya Pengintegrasian Sains dan Ilmu Agama, Tawaran Epistemologi Islam bagi Universitas Islam Negeri. Prosiding Halaqoh Nasional \& Seminar Internasional Pendidikan Islam, FTIK UIN Surabaya. 